\title{
タグボート推進器後流による曳引力減少に関する一検討 一深水域の模型実験一
}

定兼 廣行* ·境 善行**

\section{A Study on the Towing Force Reduction due to the Jet Stream Caused by Tug Boat Propeller - Model Experiment in Deep Water-}

\author{
Hiroyuki SADAKANE and Yoshiyuki SAKAI
}

\begin{abstract}
We have well known that the towing ability of a tugboat decreases because of a reaction of the jet stream caused by tugboat propeller, which acts on the ship hull of a VLCC. However at present, this fact has not yet been taken into account in the estimation of towing force. Maybe it is the reason that the influence of the jet stream on the towing force is not examined exactly and systematically and also series data on the reduction of towing force are not shown.

In this paper, the change of the towing force reduction relating to the length of towing line was studied experimentally. Model experiments were carried out by using a water-tank and a pair of ship models, namely a VLCC model and a tugboat model. And two kinds of examination conditions were selected, namely (1) the rest condition which both ship models were fixed by two dynamo-meters respectively and (2) the moving condition which the VLCC model was moved laterally by the tugboat model.

We obtained following results ;

(1) It could be confirmed that the towing force decreased by the jet stream of the tug boat propeller. And the efficiency of the towing force relating to the length of tug line was suggested based on series experiment.

(2) The above efficiency more decreased in the moving condition which the VLCC was moved by the tugboat.
\end{abstract}

\section{1.はじめに}

大型船舶がバースに離着栈する際にタグボートの 支援を受ける。そしてこのタグボートの必要能力は 曳引力を基に検討されるが、曳引力には公称曳引力 (published tug-pull) が用いられ(1)、これは普通に は建造時等に実施されるボラード試験から得る数值 である。しかし、タグボートの曳引力や押力は、タ グボート推進器が流体を加速し後方に押し出して発 生する噴流（以下では、推進器後流）の反力によっ
て生じるものであるから、この推進器後流の流れ方 や作用の如何によっては曳引力に明確な差違が生じ る。例之ば本船の離着栈について言えば、推進器後 流は本船の横移動方向つまり曳引する方向とは逆向 きに作用することとなり、タグボートの曳引力は塞 質的に減じる。このことは容易に想像できることで あるが、現在の必要曳引力算定には夕グボート推進 器後流の影響はほとんど考慮されていない。これの 理由は、推進器後流が曳引力に及ぼす影響を推定す るための信頼できる資料と合理的方法が示されてい

* 正 会 員 神戸商船大学 (下 $658-0022$ 神戸市東灘区深江南町5-1-1)

**学生会員 神戸商船大学大学院（厂658-0022 神戸市東灘区深江南町5-1-1） 
ないためであり、この種の系統的な調査や研究進展 が望まれる(2)(3)。

タグボート推進器後流による曳引力減少の程度 は、タグライン長、水深、周囲岸壁の状況、タグボー トの本船船首尾への配置場所、潮流の有無などに よって変化すると考えられる。これら種々の条件の 変化に対応して、船体の横移動速度等の制御を的確 に、安全に行うためには種々の条件や状況による曳 引能力の差違や変化に関する情報や知見が欠かせな い。またこのような曳引力変化等の実際は、タグボー 卜操船の研修や訓練などを目的とする操船シミュ レーターに取り入れることによって研修・訓練の効 果を上げることが期待できる。

本論文では水槽模型実験の手法により、夕グ操船 時に遭遇する種々の状況や条件のうち最も基本的で ある深水域・船体中央曳引に限って、タグライン長 による曳引力の減少変化を (1)船体静止状態、及び (2)船体横移動状態、の2 種類について調查する。(2) は実際の船体移動時を想定したものであり、実用的 観点から必要な実験であるが、同時に流体力学的に も而者の状態では船体周囲の流れが相違するので実 曳引力に差違が現れることが予想される。

なお、実曳引力とは夕グボートが有する曳引力で はなく被曳引物体に有効に㗢く曳引力のことであ る。

\section{2、模型実験}

実験は、本学の浅長水槽（長さ： $60 \mathrm{~m}$ ，幅：6 $\mathrm{m}$, 水深： $1.5 \mathrm{~m}$ ) において実施した。供試模型船は、1/ 100縮尺のタンカー船型とタグボートであり、各模型 船の主要目と実験状態を表 1 に、また模型の外形を 写真 1 と写真 2 に示す。タンカーの載貨状態は半載 状態である。このタンカ一模型船は半載状態で方形 係数Cbが0.74であり、比較的スマートである。この タグボート模型船はアジマスサークル・ドライブ . プロペラ (A.D.P) を装備しており、40 gfから50gf

\section{表 1 供試模型船主要目}

\begin{tabular}{|c|c|c|c|c|c|c|}
\hline \multirow{2}{*}{ Ship model } & Length & Breadth & Draft & \multirow{2}{*}{$\begin{array}{r}\text { Ship Weight } \\
(\mathrm{kgf})\end{array}$} & \multirow{2}{*}{$\begin{array}{c}\text { Block Coe. } \\
\mathrm{Cb}\end{array}$} & \multirow[t]{2}{*}{ Load Con. } \\
\hline & Lpp $\quad(\mathrm{cm})$ & B $\quad(\mathrm{cm})$ & $\mathrm{d} \quad(\mathrm{cm})$ & & & \\
\hline tanker & 300.0 & 48.0 & 11.7 & 109.2 & 0.74 & Half \\
\hline Tugboat & 39.0 & 10.6 & 4.6 & 1.035 & - & - \\
\hline
\end{tabular}

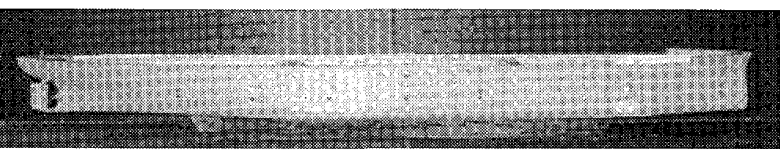

写真 1 供試タンカー模型船
の推力を出力できる。この模型船には検力計を取り 付け、この検力計でタグボート推力を検出した。

今回は初期研究であるので、複雑な影響は排除す ることとして実験は深水域を想定して水深喫水比5. 0とした。また普通には夕グボートの支援を受ける船 舶の後方には岸壁等が存在するが、これも排除した。

実験は 1 章後半に述べたように、(1)船体静止状態、 及び(2)船体横移動状態、を計画したので、以下に各 状態における実験装置等を述べる。

（1）船体静止状態の実曳引力計測装置

この状態ではタグラインを取らず、図 1 に示すよ うに配置したタンカー模型船とタグボート模型船は 各検力計を介して台車に固定される。この後、夕グ ボートのプロペラを駆動させてタグボートに推力

(曳引力) $F_{t}$ を与之、推進器後流を発生させる。そ してこの後流によって生じるタンカ一模型船への流 体反力 $F_{s}$ をンカーの検力計で計測する。 $F_{s}$ が曳 引力の減少分となる。両模型船の間隔をタグライン 長leとしてこれを20、40、100、120 cmに変えて実験 する。この距離は実践対応では20、40、100及び 120

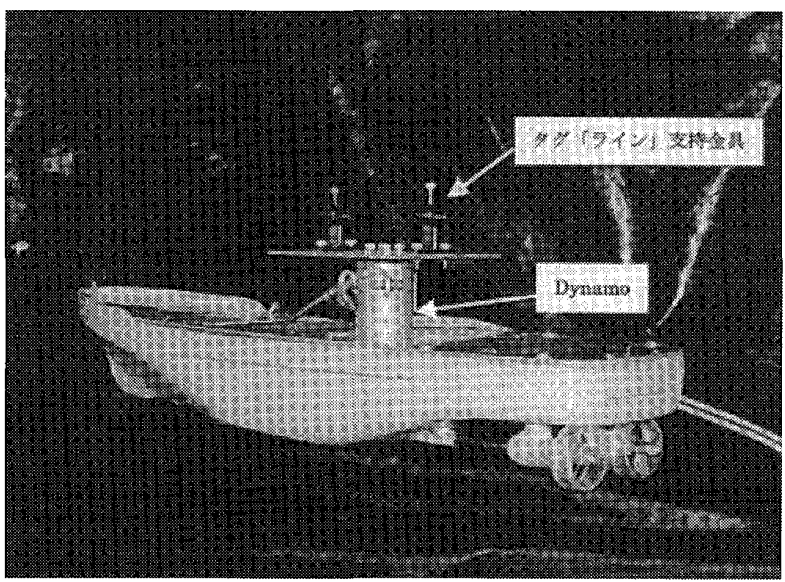

写真 2 供試タグボート模型船

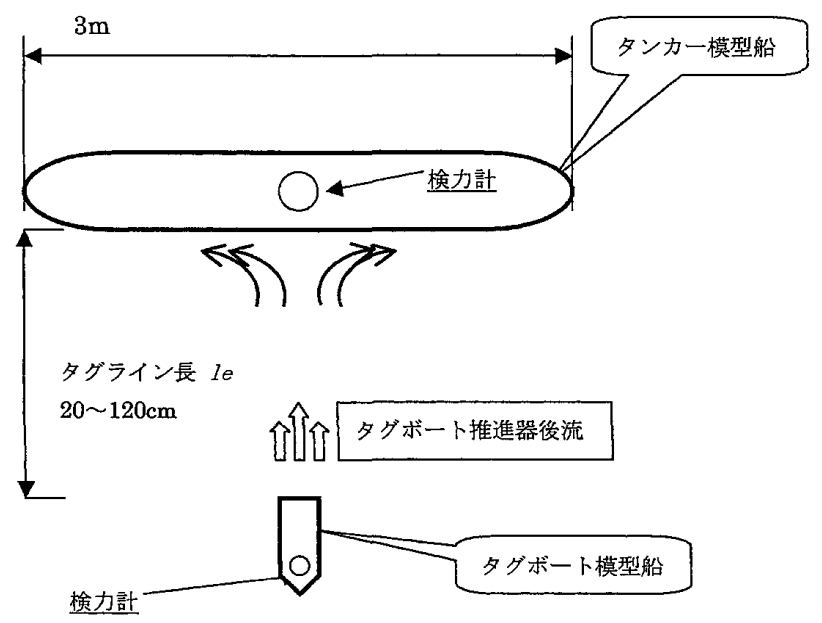

図 1 船体静止時の実験装置配置図 
mに相当する。タグボートは本船のほぼ船体中央に 配置した。船体中央は推進器後流の影響が最も顕著 に現れる場所として選ばれた。

（2）船体横移動状態における実曳引力解析の実験

この状態での実曳引力の解析方法は後の 4 章で説 明する。ここでは実験装置について述べる。この実 験においては、実際にタグボート模型船にタンカー 模型船を曳かせるため夕グラインに相当する金属製 の固着パイプを雨船間に設置した。「ライン」を固着 パイプとしたのは夕グボートの振れを抑え、安定し て曳かせるためである。両船は一体物体として夕グ ボートの曳引力によって横移動する。具体的実験方 法については4.2節に述べる。

\section{3．船体静止状態における実曳引カの調査}

本章では船体静止状態の実験方法及び結果につい て述べる。

\section{1 実験方法}

タンカ一模型船はヒービング・ロッドと検力計を 介して横行台車に固定される。図 1 に示すタンカー 模型船に設置の検力計でタグボート推進器後流によ ク生じる流体力反力を計測する。これが 2 章で述べ た曳引力の減少分となる。一方、夕グボート模型船 に設置の検力計からプロペラ駆動によって発生する 曳引力が計測されるので、両者の差から実曳引力を 抽出することができる。これらの力の電気信号はA/ $\mathrm{D}$ 変換器を通して時系列データとしてコンピュータ に記録した。

\section{2 解析方法}

夕グボートの曳引力 $F_{t}$ と、タン力ー模型船が受け たタグボートの推進器後流の流体反力 $F_{s}$ との差が 実曳引力 $F_{t a}$ となる。つまり、

$$
F_{t a}=F_{t}-F_{s}
$$

またタグボートの発生曳引力 $F_{t}$ に占める実曳引力 $F_{t a}$ の割合を実曳引力比 $\eta_{t a}$ と定義市ることができ る。つまり、

$$
\eta_{t a}=F_{t a} / F_{t}
$$

タグボート模型船を作動させた後、 $F_{t}$ と $F_{s}$ が定 常となったところからそれぞれの平均的な值を読み とり(2)式を用いて各タグライン長leにおける実曳 引力比を比較すればタグライン長による、推進器後 流影響や実曳引力の変化を見ることができる。次節 にこれを示す。

\section{3 結果}

笑曳引力比 $\eta_{\mathrm{ta}}$ の実験解析值を図 2 に×印で示す。 縦軸に実曳引力比 $\eta_{\mathrm{ta}}$ を、横軸にタグライン長leを 取っている。なお、この横軸leも無次元値で表示する
のが望ましいが、これについては、流体力学的には タグライン長を本船幅 $B$ または喫水 $d て ゙$ 無次元化し たもの、もしくは実用的にはタグボート船長で無次 元化したものがよいと考えられる。しかし現在はど ちらが好ましいかは判断できないので、今回は模型 スケールのままとした。罒中の×印は数個の実験解 析值の平均を示している。実線は実曳引力比を対数 近似した平均曲線である。対数近似は夕グライン長 leが無限に長くなると実曳引力比は一定值に収束す るという仮定のもとに行った。平均曲線は次式のよ うに表示される。

$$
\eta_{t a}=0.1206 \ln (l e)+0.1894
$$

この平均曲線の相関係数は 0.9605 であった。

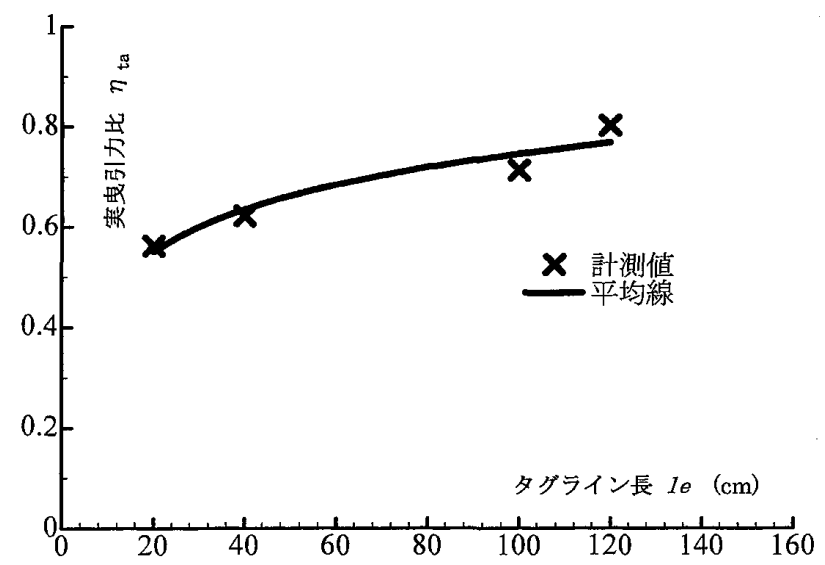

図 2 船体静止状態におけるタグライン長leと計測 実曳引力比 $\eta_{t a}$ との関係（縮尺 $1 / 100$ 模型）

\section{4 まとめ}

船体静止状態における実曳引力比は夕グライン長 $20 \mathrm{~cm}$ で0.55、40 cmで0.6强、100 cmで約 $0.75 、 120$ $\mathrm{cm}$ で約 0.8 弱、また図の平均線から $140 \mathrm{~m}$ の数值を外 挿すれば実曳引力比は約 0.8 となる。この実験結果か ら推進器後流が串引力に及ぼす影響の傾向と程度を 知ることができ、この結果はタグラインが相当に長 い、 $100 \mathrm{~cm}$ (タグボート船長の約 3.6 倍) であっても 曳引力には約 $20 \%$ 程度の減をもたらすことを示して いる。一方で意外にも、タグライン長 $20 \mathrm{~cm}$ (タグ ボート船長の㧍よそ半分）のごく短い場合であって も実曳引力比は約 0.55 であり、曳引力の減少分は約 45\%に止まっている。

上記は船体が静止している場合の特殊例であるの で、次章では移動中の場合について検討する。

\section{4. 船体横移動状態における実曳引力の 解析}

\section{1 解析方法}

前章では両模型船を固定してタンカー模型船に働 
く流体力とタグボート推力（曳引力）を直接検出し た。しかし、実際のタグボート支援操船では夕グボー 卜が本船を或いて共に移動する。そこで、夕グボー 卜模型船でタンカー模型船を実際に曳引させる実験 を行った。しかしこの実験では、タンカー模型船を 自由にするためこれに働くタグボート推進器後流の 影響を直接検出することは不可能である。そこで、 次の解析方法に従って実曳引力を推定する。

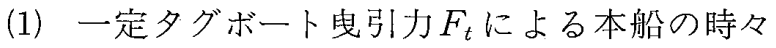
刻々の横移動距離を計測する。

（2）横移動の運動方程式を用い、これを解いて(1) の横移動距離 $s$ と比較して、上記(1)の移動距離 曲線と(2)の解曲線が合うように(2)の運動方程式 中の曳引力を決める。

(3) この曳引力を実曳引力 $F_{t a}$ と見なし、実曳引

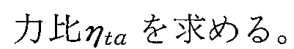

上記の手順で問題になるのは、(2)の運動方程式を 適切に定めることであるが、現段階では単純を旨と して次式を用いる。

$$
\ddot{s}=\frac{1}{M}\left(F_{t}-\frac{1}{2} \cdot \rho \cdot C_{w y} \cdot L \cdot d \cdot v_{y}^{2}\right)
$$

ここに、 $s$ : 船体の横移動距離、 $M$ : 船体横方向の見 掛質量、 $\rho$ : 水の密度、 $L$ : 船の長さ、 $d$ : 喫水、 $C_{w y}$ : 横力係数、 $v_{y}$ : 横移動速度、また “は時間による 2 回微分を表す。

なお (4) 式は曳引力 $F_{t}$ の作用によって船体は真横

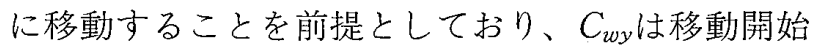
初期においては船体移動距離／経過時閒によって顕 著に変化するので過渡的横力係数 ${ }^{(4),(5)}$ を使用する。

\section{2 実験方法}

実験装置の配置図を後の四 3 に示す。タグライン 長leは20、40、80、140 cmに設定した。タグボートの プロぺラを作動させて所定の曳引力 $F_{t}$ (夕グボート の検力計で検出）でタンカ一模型船を曳引し、この 模型船の時々刻々の横移動距離を図上方に示す超音 波式変位センサーにより検出する。

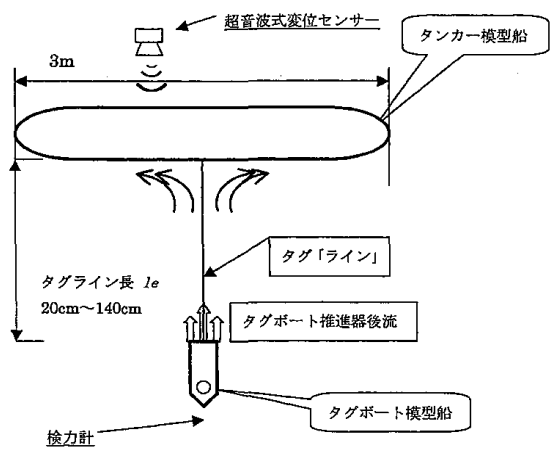

図 3 船体移動時の実験装置配置図

\section{3 実験と計算との比較}

実験と計算の結果を図4に示す。縦軸に横移動距離 $s$ を横軸に時間 $t$ を取っている。上から図 (a)、(b)及 び (c) はそれぞれタグライン長が20、80、及び $140 \mathrm{~cm}$ の結果であり、細い波形実線が実験で得られた横移 動曲線(1)、太い実線が夕グボートの曳引力 $F_{t}$ を(4) 式に入れて計算した横移動曲線(2)、点線の曲線(3)は 上記(1)の横移動曲線に合うように(4)式のタグボー 卜曳引力を選んで求めた横移動曲線である。この戋 引力を実曳引力 $F_{t a}$ とするのである。

タグボートの設定曳引力 $F_{t}$ がすべて有効に作用

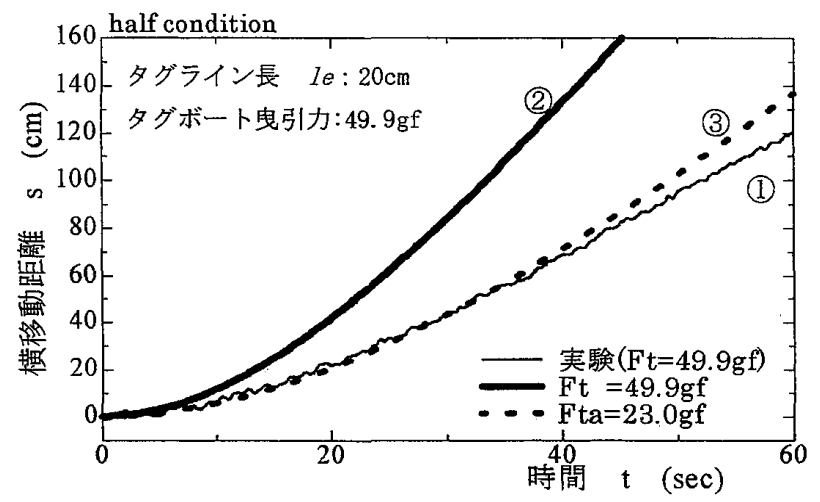

(a) タグライン長さ $20 \mathrm{~cm}$

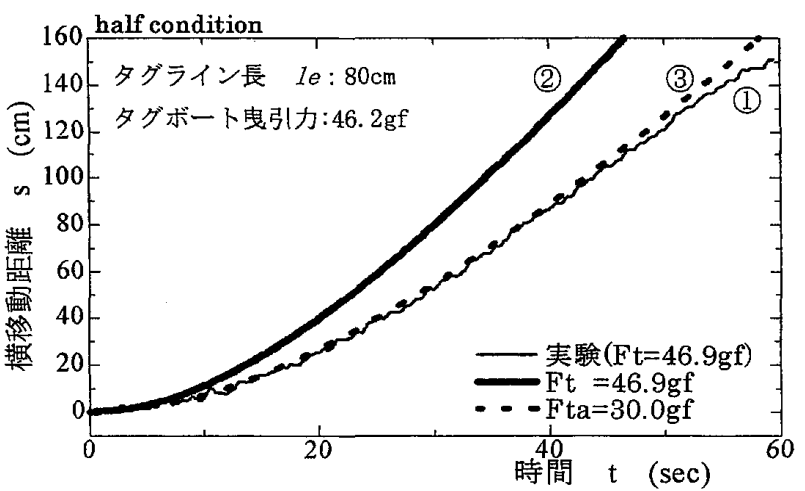

(b) タグライン長さ $80 \mathrm{~cm}$

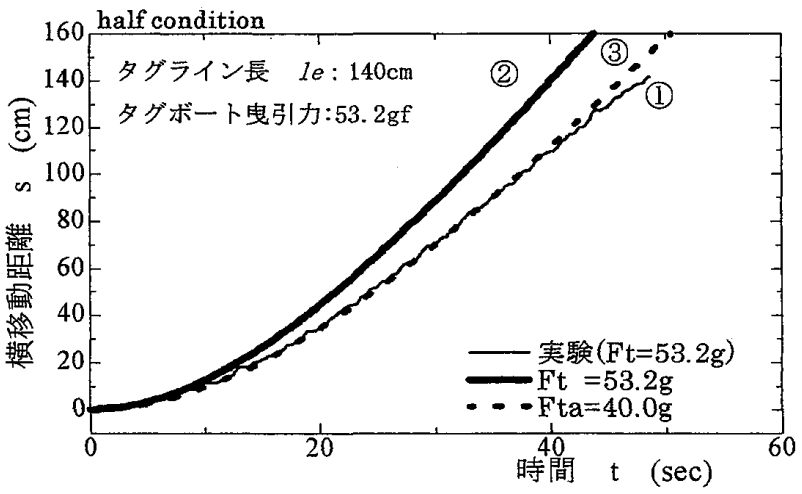

(c) タグライン長さ $140 \mathrm{~cm}$

困 4 各夕グライン長leによる船体横移動運動の 違い（実験計測、計算の比較） 
したならば実験の実線(1)は太線(2)と一致するはずで ある。しかし、船体が移動を開始した直後こそ一致 しているが、移動距離が伸びるにつれて差が生じ、 やがてその差は大きくなっていく。曲線(1)と(2)のこ の差が夕グボート推進器後流の影響の現れである。 この差はタグライン長が $120 \mathrm{~cm} の$ (c) 図の場合では 少なくなってくる。

曲線(3)は実験曲線(1)に合うように曳引力を調整し たものであるが、タグライン長の違いに封しても雨 曲線は良く一致しており、これは方程式(4)の妥当性 を示していると考えることができる。図 4 (b)の場 合について夕グボートの発生曳引力 $F_{t}$ と実曳引力 $F_{t a}$ とを比較すると、46.9 gfと $30.0 \mathrm{gf}$ となり、これは 約 $35 \%$ の曳引力減少である。なお図 4 は単に時間経 過に対して模型実験と計算結果が一致することを示 के。

\section{4 実曳引力比の推定}

前節 4.3 で示した実験と計算の比較から実曳引力 $F_{t a}$ が解析できたので、実曳引力比 $\eta_{t a}$ を求めること ができる。

結果を図 5 に示す。船体静止時と同様、縦軸に実 曳引力比を、横軸にタグライン長leをとっている。 印は解析值を示している。実曳引力比 $\eta_{t a}$ は夕グラ イン長さ $20 \mathrm{~cm}$ で0.46、 $40 \mathrm{~cm}$ で0.55、80 cmで0.64、 $140 \mathrm{~cm}$ で 0.75 となった。点線は船体静止時と同様、 対数により近似した平均曲線である。この曲線は次 式で表される。

$$
\eta_{\mathrm{a}}=0.1463 \ln (l e)+0.01469
$$

平均曲線の相関係数は0.9949である。

\section{5 まとめ}

船体横移動状態においては、実曳引力を直接計測 することができないため、船体横移動距離の計測と 運動方程式の解曲線を比較することによって実曳引

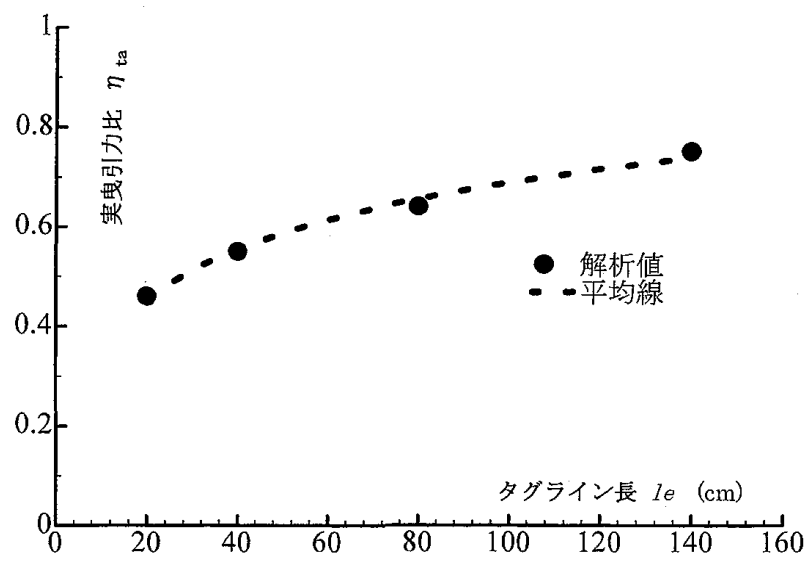

困 5 船体横移動中における夕グライン長leと解析 害曳引力比と $\eta_{t a}$ との関係（縮尺 $1 / 100$ 模型）
力を解析した。船体静止状態と同様、夕グライン長 leが長いほど実曳引力比が大きくなる結果を得た が、これを船体静止時と比較すると全体に横移動時 の方が低めに現れた。これについては次章で述べる。

\section{5. 議論}

\section{(1) タグライン長の影響}

船体の静止状態、移動状態ともに実曳引力比は夕 グラインが長いほど大きくなり、曳引効率が上がる ことが示された。これはタグラインが長いほどタグ ボート模型船の推進器によって加速された噴流が夕 ンカ一模型船の舷側に至るまでに減衰が進むためで ある。また、夕グラインが長い場合は夕グボート模 型船の推進器によって加速された水流の拡散が生じ るため、この水流の下部はタンカ一模型船の船底を 迂回して後方に抜けるが、タグラインが短い場合は、 加速された水流はまだ十分に拡散していないのでこ の水流の主要部分がタンカー模型船の船側に当たり 流体反力を強めるためである。

（2）船体の静止時と移動時の実曳引力比

4.5節後半に船体の移動状態の実曳引力が静止状 態に比べて低く現れたことを述べた。図 6 に船体静 止状態と船体移動状態の実曳引力比の比較して示 す。船体移動状態の力が船体静止状態より低い值を 示している。これは、船体静止状態では船体には夕 グボートの推進器後流のみが作用しているが、船体 移動状態では船体が移動することによって船体周囲 に固有の別な流れが生じるため、推進器後流のflow patternが変化したことと、船体が移動することに よって推進器後流の拡散が少し抑えられたため後流 の噴流速度が強まったと考えられる。

上記はまだ推測の域を出ておらず、差違の原因に ついては今後の検討に待つことになる。

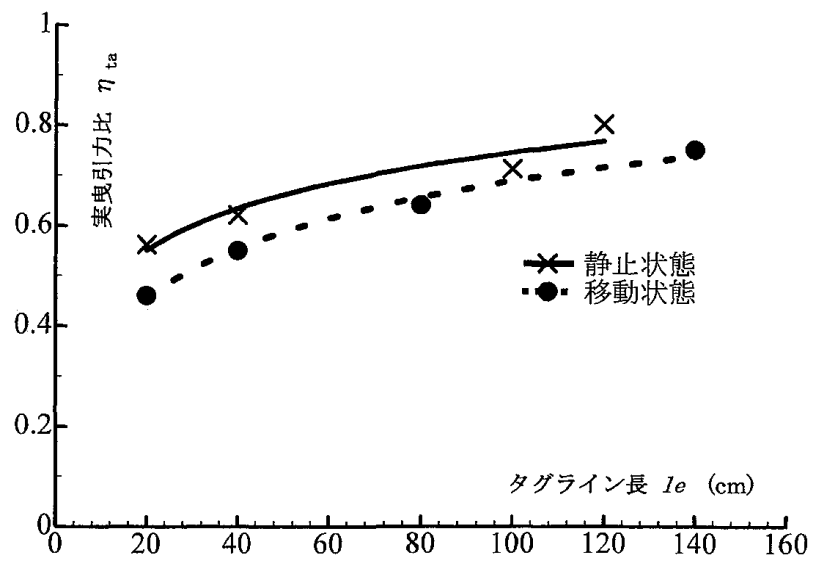

困 6 船体の静止状態と移動状態における実曳引力 比 $\eta_{t a}$ の比較（縮尺 $1 / 100$ 模型） 
（3）実験における縮尺影響

今回の研究は推進器後流が曳引力に及ぼす影響の 存在を確認し、合わせてその傾向を調査するのが目 的である。これらについては模型実験で事足りるの で、縮尺影響についての検討は後日の課題となる。

\section{6.おわりに}

本論文では、模型実験を通し、タグボートの推進 器後流が曳引力の減少を引き起こすことを指摘し、 それらを評価する指標として実曳引力比を提案し た。以下に本研究で得られた結果をまとめる。

(1) 夕グボートの推進器後流により或引力は減少 することを模型実験により確認した。そしてそ の程度を、タグラインがタグボート船長の0. 5３.6倍の範囲について調査し、ラインは長い ほど曳引効率はよい。

（2）船体静止状態と船体移動状態では夕グライン 長さによる実曳引力比の傾向は同様の結果と なったが、実曳引力比は船体移動状態の力が低 めに現れた。

(3) 曳引力の減少は夕グボートの推進器後流によ る減少の他に船体移動によって生じる減少があ る。

今回は深水域で船体中央曳引のみの検討を行っ た。しかし実際のタグボート支援操船では浅水域で あるため、浅水域の実験も行う必要がある。また船 体周辺の岸壁等の影響についても調査の必要がある かも知れない。これらは今後の課題としたい。

最後に本研究の実験と解析の一部は当時第 4 学年 出野耕太君、山崎良太君の卒業研究として行われま した。ここに記して謝意とします。

\section{参 考 文 献}

（1）本田啓之輔：二港揚げVLCC離着栈横移動時の
夕グ所要支援力, 日本航海学会論文集 第 80 号, pp. 17 24, 1988.

（2）（社）日本作業船協会：引船の曳航力に関する設 計指針の調查研究，報告書，昭和54年 3 月.

（3）中島利雄：曳船操船一そのテクニックー 海文 堂 昭和 54 年 12 月。

（4）定兼廣行：静止から横移動を開始する船体の横 力係数に関する検討，日本航海学会論文集 第 95号，pp.193 200， 1996.

（5）定兼廣行・鶴田広已：静止から横移動を開始す る船体に働く過渡的流体力 一模型実験による 検討一，日本航海学会論文集 第90号，pp. 273 279, 1993.

\section{質 疑 応 答}

佐藤治夫 (東海大学海洋学部)：タグライン長さによ る分析をされていますが、タグボートの馬力が大 きい場合は、どのようになるでしょうか。

境 善行：今回は夕グボートの馬力は 1 種類しか実 験を行っていません。今回の実験から推測します と、馬力が大きくなるということは、推進器後流 の影響も大きくなることを意味します。そのため、 実曳引力比は小さくなると考之ます。その場合、 タグライン長による傾向は同様になると考えられ ます。

松本朋子(古野電気株式会社)：実験を行った夕グラ イン長はどのようにして決めたのでしょうか。

境 善行：実験施設の制約上タグライン長を最大 $140 \mathrm{~cm}$ とました。また、タグラインが非常に短 い場合を考え、タグボート船長の約半分の長さに 相当する、 $20 \mathrm{~cm}$ から $140 \mathrm{~cm}$ までの実験を行いま した。実用上はこの範囲に内に収まっていると考 えます。 